\title{
Organization MANAgEMENT THROUGH MOTIVATING EMPLOYEES
}

\author{
ZARZĄDZANE ORGANIZACJĄ \\ POPRZEZ MOTYWOWANIE PRACOWNIKÓW
}

\begin{abstract}
In the era of strong market competition, the most important goal of entrepreneurs is the development of the company (organization), strengthening its position on the market and gaining benefits. Meeting this task lies in efficient management stimulating employees to work effectively. Research in this area shows that building an appropriate incentive system is an important element of management. In management, motivation is expressed as the ability to combine the goals of individual employees with the goals of the company. The following article describes issues related to motivating employees and presents the development and importance of the theory of motivation in practical operation.
\end{abstract}

\section{STRESZCZENIE}

W dobie silnej konkurencji rynkowej najważniejszym celem przedsiębiorców jest rozwój przedsiębiorstwa (organizacji), umacnianie jego pozycji na rynku i osiąganie korzyści. Sprostanie temu zadaniu zależy od sprawnego zarządzania pobudzającego pracowników do efektywnej pracy. Badania w tym zakresie wykazują, że ważnym elementem zarządzania jest zbudowanie odpowiedniego systemu motywacyjnego. W zarządzaniu motywacja jest wyrażona jako umiejętność 
połączenia celów poszczególnych pracowników z celami przedsiębiorstwa. Poniższy artykuł opisuje zagadnienia związane z motywowaniem pracowników i przybliża rozwój oraz znaczenie teorii motywacji w działaniu.

KEYWORDS: motivation, motivating, payroll and non-payroll motivation factors, human capital, management, labor market

SŁOWA KLUCZOWE: motywacja, motywowanie, płacowe i pozapłacowe czynniki motywacji, kapitał ludzki, zarzadzanie, rynek pracy

\section{WPROWADZENIE}

Organizacje wywierają kolosalny wpływ na życie człowieka, na jego rozwój i poziom oraz zawodową przyszłość. Prowadzenie organizacji jest sztuką wymagającą nie tylko zarządzania kapitałem finansowym i zastosowania nowoczesnych technik i technologii, ale także umiejętności pracy z pracownikami. Pracownicy stanowią kapitał ludzki, najważniejszą część każdej organizacji. Sukces organizacji w dużej mierze zależy od ich zaangażowania w pracę i umiejętności zawodowych, które powinny być wsparte odpowiednią motywacją, gdyż same umiejętności i kwalifikacje nie są wystarczające do zapewnienia firmie sukcesu. Niezbędnym i istotnym czynnikiem, prowadzącym do efektywnego wykorzystania walorów posiadanych przez pracowników, jest odpowiednia motywacja. Umiejętnie zmotywowani pracownicy wydatnie przyczynią się do zwiększenia osiągnięć i rozwoju przedsiębiorstwa. Obecnie coraz więcej przedsiębiorstw wdraża nowy, innowacyjny model biznesowy opierający się na otwartości na nowe technologie pochodzące z ich otoczenia. Do najważniejszych zjawisk, które bezpośrednio przyczyniają się do zmiany metod i form zarządzania należą:

- zmieniający się rynek pracy, który prowadzi do różnicowania kompetencji kierowniczych;

- zmiany form kooperacji przedsiębiorstw, które prowadzą do profesjonalizacji roli kierownika (np. powstawanie przedsiębiorstw wirtualnych);

- umiędzynarodowienie zarządzania, które wymaga nabycia nowych umiejętności kierowniczych (np. dostosowania kulturowego);

- rozwój mechanizmów dyscyplinujących, które prowadzą do decentralizacji roli menedżerów; 
- nowe style zarządzania i inne formy przywództwa;

- wzrastająca odpowiedzialność społeczna przedsiębiorstw.

W zmieniającej się rzeczywistości kształtowanie motywacji nadal jest niezbędnym elementem pracy każdego menadżera, który ma do dyspozycji szereg motywatorów do wykorzystania przy opracowywaniu odpowiedniej strategii motywacji do pracy, zapewniającej ustawiczne zaangażowanie pracowników na rzecz sukcesu przedsiębiorstwa, zachęcającej do podwyższania przez nich kwalifikacji i dającej im realną satysfakcję z pracy. Motywowanie pracowników do uruchomienia swoich potencjalnych możliwości i umiejętności, kreatywności i pomysłowości, a także pełnego zaangażowania się w realizowane przez siebie zadania jest pierwszoplanową rolą kadry kierowniczej.

W tym opracowaniu starano się przybliżyć potencjalnemu czytelnikowi istotę i cele motywowania pracowników oraz znaczenie procesu motywowania dla rozwoju przedsiębiorstwa. Wymienione teorie motywacji świadczą o wadze problemu i konieczności wykorzystania wiedzy naukowej w nowoczesnym zarządzaniu organizacją.

Artykuł składa się z trzech części, którymi są:

1. Istota motywacji.

2. Wybrane teorie motywacji.

3. Motywowanie pracowników jako istotny element nowoczesnego zarządzania.

\section{ISTOTA MOTYWACJI}

Motywacja w teorii zarządzania jest czynnikiem wyznaczającym poziom, kierunek i trwałość wysiłków podejmowanych w pracy (Schermerhorn, 2008, s. 259). W literaturze przedmiotu pojawia się wiele określeń motywacji. Według słownika Władysława Kopalińskiego, pojęcie „motywacja” wywodzi się z łacińskiego słowa motus (poruszyć, wprawić w ruch) i francuskiego motiv (powód, motyw) i oznacza uzasadnienie, wyjaśnienie pobudek (Kopaliński, 2002, s. 501).

Stanisława Borkowska motywację wyjaśnia jako ogół motywów, które wpływają na decyzję człowieka o zachowaniu, podjęciu zachowania, jego podtrzymaniu lub kierunku (Borkowska, 1985, s. 9). Nieco inaczej motywację 
rozumie Józef Penc, który uważa, iż „motywacja odnosi się do wewnętrznych, psychicznych przeżyć człowieka, od których zależy możliwość i kierunek ludzkiej aktywności. Jest ona swego rodzaju czynnikiem regulacji, który steruje czynnościami człowieka tak, aby osiągnął określony cel” (Penc, 2000).

Podobną definicję motywacji przedstawiają James A. Stoner, Edward R. Freeman i Daniel R. Gilbert (1999, s. 426):

„Motywacja to stan gotowości istoty rozumnej do podjęcia określonego działania, to wzbudzony potrzebą zespół procesów psychicznych i fizjologicznych określający podłoże zachowań i ich zmian, psychologiczny stan przyczyniający się do stopnia, w jakim człowiek się w coś angażuje; obejmuje ona czynniki, które powodują, wytyczają i podtrzymują zachowanie ludzkie zmierzające w określonym kierunku”.

Możemy więc przyjąć, że motywacja to siła pobudzająca do działania i ukierunkowująca je na określone cele, obejmująca szereg procesów zaangażowanych w rozpoczęcie, kierowanie i podtrzymywanie aktywności fizjologicznych i psychicznych człowieka. Proces motywacji możemy podzielić na cztery fazy:

I faza - gotowość do działania, czyli motyw;

II faza - wybór sposobu działania prowadzący do osiągnięcia celu;

III faza - etap konkretnych działań;

IV faza - satysfakcja z osiągniętego rezultatu działań (lub jej brak).

Istotę motywacji trafnie ujął T. Kotarbiński, stwierdzając, że: „podstawowym rozwiązaniem problemu motywacji jest to, by człowiek robił ochoczo to, co robić musi, by tego, co robić musi, nie robił dlatego, że musi, by w robieniu tego, co musi, znalazł upodobanie i dzięki temu pracę swą usprawnił wielokrotnie, okazując hojność w oddaniu się jej” (Mroziewski, 2005, s. 143).

Literatura przedmiotu (Koperyńska, 2008, s. 17-18), wyróżnia trzy poziomy motywacji:

1. Podporządkowanie: pracownik wykonuje to, co każe przełożony, tak jakby sam nie potrafił myśleć i nie miał żadnych uzdolnień.

2. Identyfikacja celu: rodzi pragnienie osiągnięcia celu. Aby móc osiągnąć drugi poziom, trzeba wyraźnie zakomunikować pracownikowi korzyści płynące $z$ rezultatu. 
3. Zaangażowanie: na tym poziomie pracownik uważa cel za własny. Aby osiągnąć trzeci poziom, pracownik musi pojąć, że jest jedyną osobą, której powierzono dane zadanie i poczuć, że dobra praca leży w jego interesie.

Rysunek 1.

Fazy motywacji
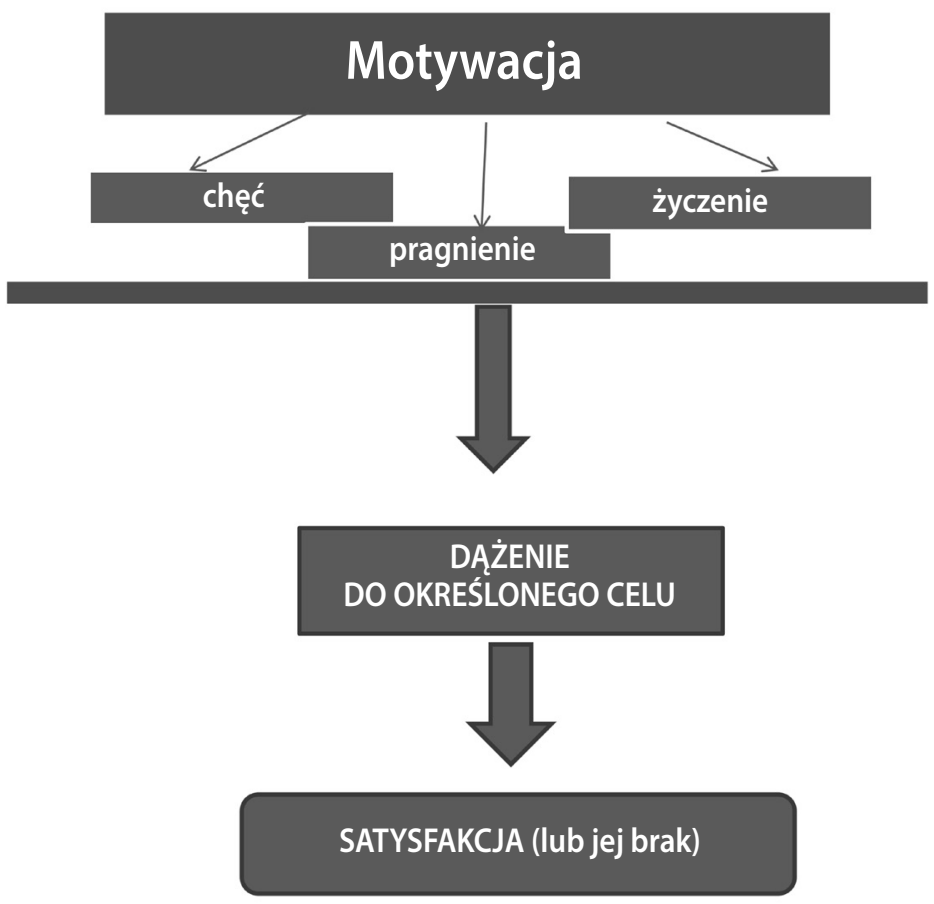

Źródło: opracowanie własne.

\section{WYBRANE TEORIE MOTYWACJI}

Rozwój teorii motywacji wiąże się z przekonaniem, że wewnętrzne potrzeby człowieka i chęć ich zaspokojenia determinują jego działanie w określonym kierunku.

Teorie motywacji można prezentować w różnych ujęciach: jako teorię potrzeb (A.H. Maslow), osiągnięć (D.C. McClelland), oczekiwań (V. Vroom), sprawiedliwości (J.S. Adams). 


\section{A. Tradycyjna teoria Taylora}

Już w XIX w. Frederick Winslow Taylor (1856-1915), amerykański ekonomista, inżynier i wynalazca, w pracy Zarzadzanie warsztatem wytwórczym (1903, wyd. polskie 1926), przedstawił model motywacji, opierający się na idei człowieka o nazwie Homo Economicus. Homo Economicus to człowiek kalkulujący korzyści i wybierający alternatywę przynoszącą mu największe korzyści materialne. Jego zdaniem podstawową motywacją jest motywacja ekonomiczna. Taylor zakładał, że człowieka najbardziej zmotywuje do wydajnej pracy system odpowiednich kar i nagród, stosowanych przez pracodawcę. Pracodawca ustala warunki pracy i płacy, a pracownik jest zobowiązany do jej wykonania. Elementy takiego motywowania, zwanego obecnie tradycyjnym, stosowane są również we współczesnych firmach, szczególnie małych, którymi właściciel zarządza autokratycznie.

\section{B. Teoria Maslowa - hierarchia potrzeb}

Wraz z rozwojem ruchu human relations pracodawcy zrozumieli, że tradycyjne podejście do motywacji pracowników nie jest wystarczające. Badacze stosunków międzyludzkich Elton Mayo (1880-1949), Hugo Münsterberg (1863-1916) i inni stwierdzili, że oprócz czynników materialnych ważne są też inne potrzeby, które znaczą więcej dla pracowników niż technologiczne warunki pracy. Potrzeby społeczne, poczucie przydatności i znaczenia dla przedsiębiorstwa, własny rozwój zawodowy - to czynniki motywujące do efektywnej pracy. Na takich badaniach oparł się Abraham Harold Maslow (1908-1970) - amerykański psycholog, autor teorii hierarchii potrzeb. W roku 1954 ukazała się jego książka Motivation and Personality, w której rozwinął teorię hierarchii potrzeb ludzkich, znanej jako piramida Maslowa. Główna tematyka badań i obserwacji autora jest skupiona wokół sensu i znaczenia pracy ludzkiej. Maslow postawił tezę, że człowiek w swoim działaniu dąży do zaspokojenia zespołu potrzeb, które tworzą logiczną hierarchię, rozpoczynającą się od potrzeb niższego stopnia, a kończącą się potrzebami wyższego stopnia. 
Rysunek 2.

Piramida potrzeb Maslowa

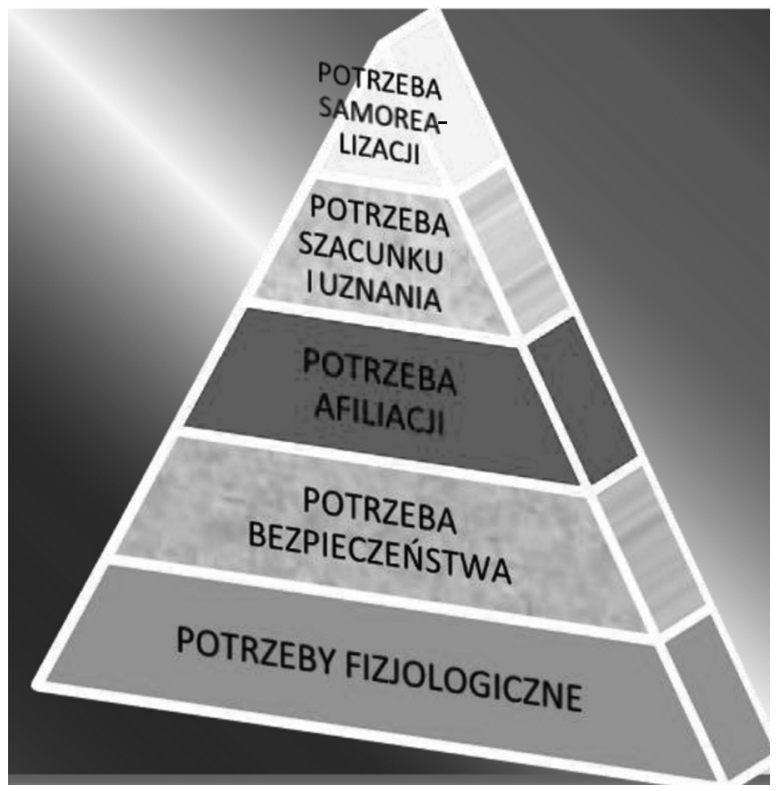

Źródło: opracowanie własne.

POTRZEBY NIŻSZEGO RZĘDU: potrzeby fizjologiczne i bezpieczeństwa.

POTRZEBY WYŻSZEGO RZĘDU: potrzeby afiliacji, szacunku i uznania oraz samorealizacji.

A.H. Maslow twierdził, że człowiek przede wszystkim musi zaspokoić potrzeby niższego rzędu, które są niezbędne w codziennym życiu. Są to potrzeby podstawowe i potrzeby stabilizacji:

- potrzeby fizjologiczne - podstawowe potrzeby człowieka konieczne do przetrwania, jak oddychanie, picie wody, potrzeba snu, odżywianie się, rozmnażanie;

- poczucia bezpieczeństwa - potrzeba zapewnienia bezpieczeństwa osobistego, wolności, stabilności, ochrony, porządku, sprawiedliwości czy wyeliminowania zagrożeń;

- przynależności - potrzeby miłości, przyjaźni, przywiązania, akceptacji. 
Gdy potrzeby niższego rzędu zostaną zaspokojone, przestają stanowić źródło motywacji, gdyż często pracownicy uważają, że należy im się to automatycznie $z$ racji zatrudnienia.

Po zaspokojeniu potrzeb niższego rzędu możliwe jest zaspokajanie potrzeb wyższego rzędu, związanych z osobowością człowieka. Wraz z rozwojem osobowości zauważa się większą motywację do zaspokajania potrzeb wyższego rzędu.

- szacunku i uznania - potrzeby uznania, prestiżu i szacunku własnego i ze strony innych ludzi; pragnienie wolności, dobrego statusu społecznego, sławy, dominacji.

- samorealizacji - potrzeby samorealizacji wyrażają się w dążeniu człowieka do rozwoju swoich możliwości, w tym zaspakajaniu potrzeb estetycznych (potrzeba harmonii i piękna) i poznawczych (potrzeby nabywania wiedzy, rozumienia świata, nowości), oraz do realizowania własnych ambicji.

\section{Teoria Alderfera - teoria ERG}

Teoria Maslowa wywarła bardzo silny wpływ na późniejsze badania z zakresu motywacji pracowników. Na gruncie krytyki teorii A. Maslowa wyrosła jedna ze współczesnych teorii motywacji C.P. Alderfera, zwana teorią ERG.

Model ERG opracował Clayton Paul Alderfer (ur. 1940) - amerykański psycholog. Wyróżnił on trzy grupy potrzeb:

- potrzeby egzystencji (E - existence), odnoszące się do materialnych warunków życia człowieka (zbliżone są do potrzeb fizjologicznych i bezpieczeństwa w modelu Maslowa);

- potrzeby kontaktów społecznych ( $\mathrm{R}$ - reletendes), odpowiadające u Maslowa potrzebom przynależności i szacunku;

- potrzeby wzrostu (G - growth), obejmujące potrzebę rozwoju i samorealizacji, wzbogacania osobowości człowieka.

W przeciwieństwie do A. Maslowa, C.P. Alderfer stwierdził, że człowiek może realizować potrzeby wyższego rzędu bez zaspokojenia potrzeb niższych. Jednak wówczas może ulegać frustracji, powodującej zmianę priorytetów i chęć zaspokojenia w pierwszej kolejności potrzeb niższego rzędu. Taka interpretacja potrzeb wskazuje, że mogą one mieć dowolny charakter, zależny od sytuacji, niedający się zhierarchizować. 
W teorii Maslowa nie ma elementu frustracji i regresji. Zakładał on, że człowiek będzie pozostawać na danym poziomie hierarchii potrzeb tak długo, aż zostaną one zaspokojone. Teoria ERG sugeruje, że ludzkie działanie może być wywołane jednocześnie przez kilka kategorii potrzeb, niekoniecznie w kolejności sugerowanej przez Maslowa.

\section{Teoria dwuczynnikowa Herzberga}

Alternatywę wobec popularnej piramidy potrzeb Maslowa stanowi dwuczynnikowa teoria motywacji, zaprezentowana przez amerykańskiego psychologa Fredericka Irvinga Herzberga (1923-2000). Herzberg uważał, że czynniki motywujące pracowników do pracy można podzielić na dwie grupy: czynniki higieny (czynniki zewnętrzne) i motywatory (czynniki wewnętrzne).

\section{Rysunek 3.}

\section{Czynniki zewnętrzne i wewnętrzne}

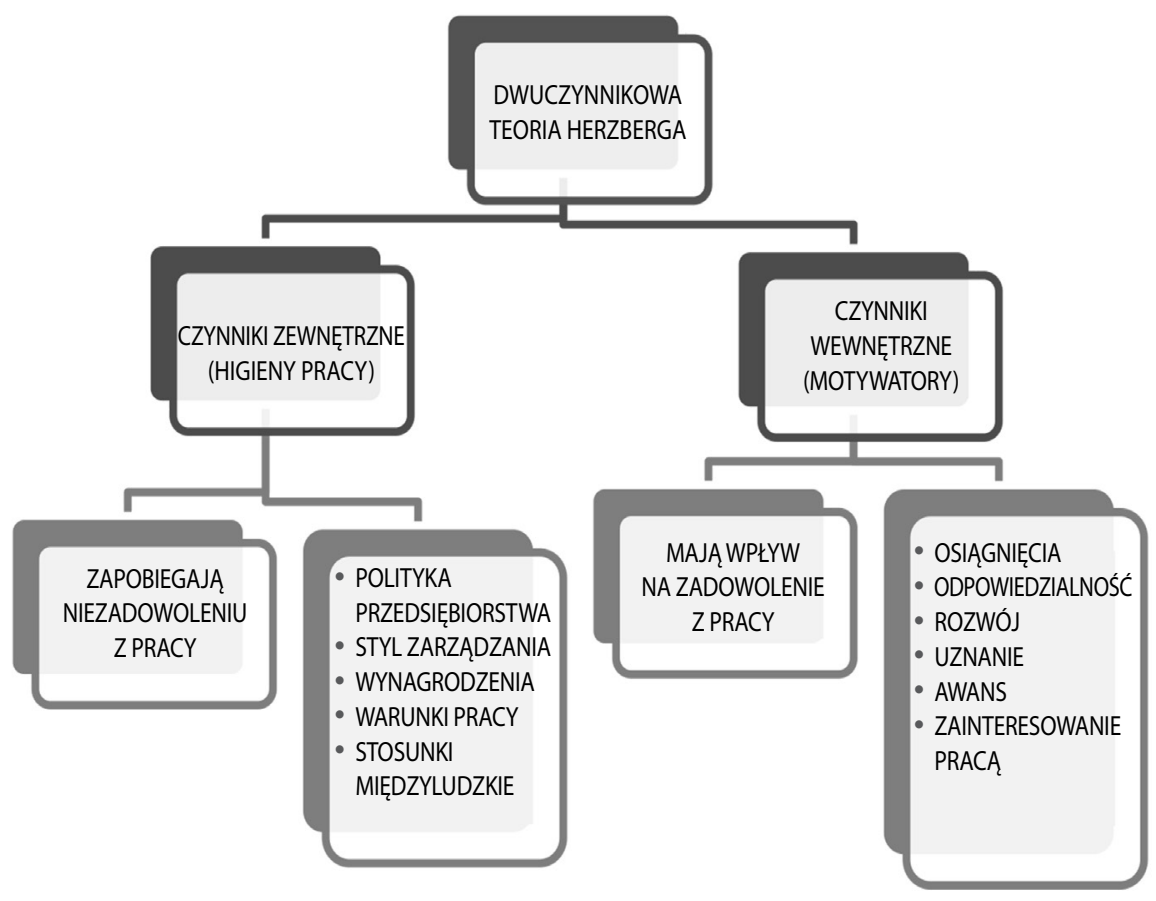

Źródło: opracowanie własne. 
F.I. Herzberg stwierdził, że do poprawnego funkcjonowania motywatorów niezbędne jest w pierwszej kolejności zapewnienie pracownikom środków higieny. Jednak skupienie się wyłącznie na czynnikach higieny nie gwarantuje osiągnięcia przez pracowników pożądanego poziomu motywacji, są one postrzegane przez podwładnych jako naturalne warunki pracy. Zapewnienie środków higieny na odpowiednim poziomie prowadzi jedynie do ograniczenia niezadowolenia pracowników oraz stanowi punkt wyjścia do zastosowania motywatorów, które są właściwym źródłem satysfakcji z pracy.

Herzberg uznał środowisko pracy za źródło środków służących zaspokajaniu potrzeb ludzi, osiąganiu zadowolenia i satysfakcji z powierzonych zadań lub niezadowolenia i frustracji spowodowanych brakiem osiągnięć. Praca odbywa się w określonych warunkach fizycznych i psychicznych. Warunki te mogą wywoływać u pracownika poczucie komfortu, bezpieczeństwa lub przeciwnie - poczucie dyskomfortu i zagrożenia. Człowiek zadowolony zawsze lepiej i wydajniej pracuje, ponieważ zaspokojenie potrzeb pozytywnie wpływa na jego postawy i zachowanie. Zrozumienie tego problemu i zapobieganie negatywnym zjawiskom w pracy należy do menedżerów, którzy powinni być zorientowani w zakresie oczekiwań, potrzeb i aspiracji podległych im pracowników.

\section{E. Teoria osiągnięć McClellanda}

Inną potrzebę istotną dla motywowania do pracy zauważył David Clarence McClelland (1917-1998), amerykański specjalista w zakresie motywacji i przedsiębiorczości. McClelland uważał, że potrzeba osiągnięć stanowi jeden z najsilniejszych czynników motywujących do pracy. Potrzeba osiągnięć uważana jest za chęć wyróżnienia się, osiągnięcia sukcesu, powodzenia w sytuacji konkurencyjnej.

Teoria McClellanda (trychotomia potrzeb) opiera się na założeniu, że jednostka posiada potrzeby w trzech zakresach:

- osiągnięć: potrzeby wykonania i demonstrowania swoich koncepcji, sukcesów, powodzenia;

- afiliacji: potrzeby miłości, przynależności do grupy, powiązania z innymi;

- władzy: potrzeby kontroli, oceny innych, autorytetu, narzucania woli. 
W ramach każdej z tych potrzeb zostały zidentyfikowane trzy charakterystyczne cechy ludzi z dużą potrzebą ich osiągania.

Ludzi z silną potrzebą osiągnięć charakteryzuje:

- chęć przyjęcia osobistej odpowiedzialności za wykonanie zadania, a jedynie w przypadku absolutnej konieczności uciekanie się do pomocy innych - wyłącznie kompetentnych osób, autorytetów i ekspertów;

- podejmowanie dobrze skalkulowanego ryzyka przy stawianiu sobie ambitnych, lecz realnych celów;

- chęć poznania oceny wyników swoich działań bez względu na jej wymiar.

Potrzeba afiliacji wyraża się w:

- dążeniu do pozyskania aprobaty,

- uleganiu autorytetom,

- zainteresowaniu uczuciami współpracowników.

\section{Potrzeba władzy to:}

- chęć wpływania lub kierowania innymi,

- potrzeba kontrolowania i oceny innych,

- chęć utrzymywania stosunków zależności funkcyjnej.

Trychotomia potrzeb Davida McClellanda znalazła zastosowanie w systemie teorii zarządzania jako teoria motywowania pracowników. Osoby wykazujące potrzeby osiągnięć ujęte w tych trzech grupach są odpowiednie na różne stanowiska.

Osoby o potrzebie osiągnięć są dobrymi kandydatami na przedsiębiorców. Ich cechy charakteru sprawiają, że sprawdzają się na kluczowych stanowiskach menedżerskich.

Ludzie o potrzebie afiliacji dzięki swoim cechom charakteru są idealni do pracy w grupie. Potrafią słuchać innych, brać pod uwagę ich sugestie. Nie spełniają się w roli przywódcy czy przełożonego.

Osoby o potrzebie władzy najlepiej czują się w roli lidera grupy. Wśród nich są osoby o potrzebie władzy społecznej lub osobistej. Ci pierwsi potrafią skutecznie przewodzić grupie, brać odpowiedzialność za innych, podejmować 
trudne decyzje, rozwiązywać problemy. Są przydatni dla przedsiębiorstwa i dla pracowników. Osoby z drugiej grupy sami podejmują arbitralne decyzje, nie znoszą sprzeciwu, nie tolerują nieposłuszeństwa, nie umieją współpracować z innymi na płaszczyźnie koleżeńskiej. Ich metody działania prowadzą do bardzo wysokiej efektywności pracy w danej grupie roboczej, jednak jej jakość i siła motywacji są niskie. Pracownicy są zaangażowani jedynie w sytuacji, gdy podlegają bezpośredniemu nadzorowi. W rezultacie oczekiwania pracodawcy i pracowników rozmijają się.

\section{F. Teoria oczekiwań Vrooma}

Na problemie oczekiwań pracowniczych skoncentrował się m.in. Victor Vroom (ur. w 1932 w Montrealu w Kanadzie), profesor psychologii na Uniwersytecie Yale, opracowując ramy teorii oczekiwań.

Rysunek 4 .

\section{Teoria oczekiwań Vrooma}

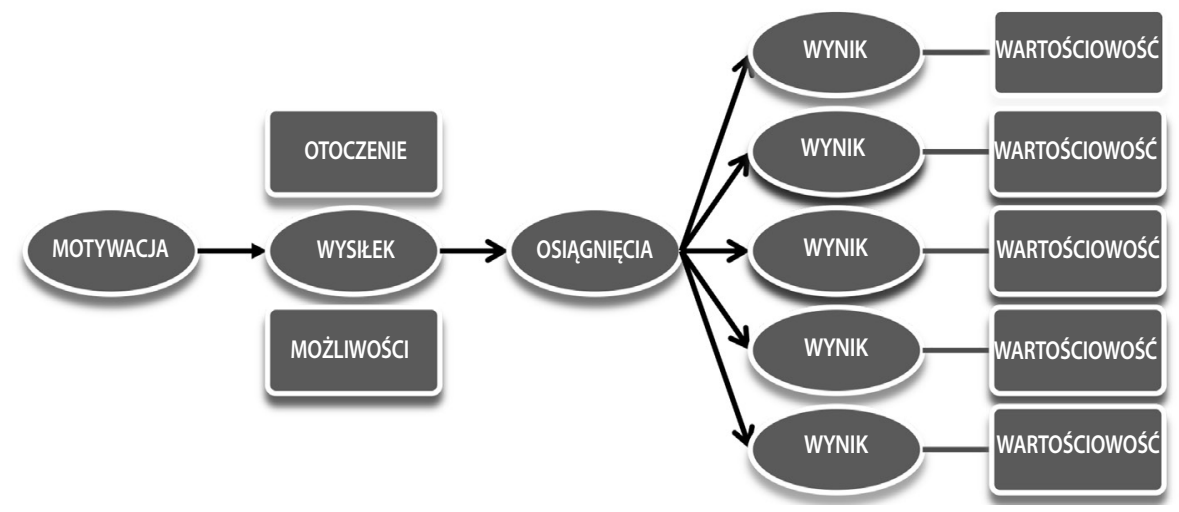

Źródło: opracowanie własne.

Na rysunku został przedstawiony typowy model oczekiwań wg teorii Vrooma. Model ten wskazuje, że motywacja prowadzi do wysiłku, który w połączeniu z możliwościami i uzdolnieniami pracownika oraz czynnikami płynącymi z otoczenia pozwala na określone osiągnięcia w pracy. Osiągnięcia te mogą dawać różne wyniki, przy czym każdy wynik będzie miał przypisaną jakąś wartość (wartościowość). 
Teoria Vrooma opiera się na założeniu, że motywacja człowieka zależy od siły pragnienia oraz prawdopodobieństwa jego zaspokojenia. Ludzie mają wybór sposobu zachowania i dokonują go, mając na względzie stopień, w jakim dane zachowanie będzie prowadziło do pożądanych rezultatów. Teoria oczekiwań stara się zauważyć i uwzględnić istniejące różnice między potrzebami ludzi i odrębność sytuacji, w których ludzie egzystują. Motywacja mobilizuje człowieka do ponoszenia wysiłku, który wraz z połączeniem jego indywidualnych predyspozycji oraz warunkami otoczenia prowadzi do oczekiwanych osiągnięć w pracy. Osiągnięcia te mają postać różnych wynikaów, które człowiek wartościuje, zakładając, że wzrost poniesionego wysiłku doprowadzi do wyższych osiągnięć. Indywidualne wartościowanie pracy opiera się na poczuciu sprawiedliwości człowieka, odczuwanego przy porównywaniu nakładów i osiągnięć własnych oraz innych pracowników.

\section{G. Teoria sprawiedliwości Adamsa}

Na tym zagadnieniu skupił się John Stacey Adams (ur. w 1925 r. w Belgii) - amerykański psycholog zajmujący się zachowaniem pracowników w miejscach pracy. W 1965 r. opracował on teorię sprawiedliwości stosowanej w ramach rozważań nad motywacją w pracy (ang. equity theory on job motivation), uważając, że pracownik porównuje bilans wkładów i efektów własnych działań w organizacji z relacjami wkładów i efektów innych osób (Chrisidu-Budnik, 2005, s. 398).

Podobną definicję podaje Józef Machaczka, profesor nadzwyczajny Akademii Ekonomicznej i Akademii Górniczo-Hutniczej w Krakowie: „według tej teorii ludzie są motywowani do poszukiwania sprawiedliwości społecznej w nagrodach, jakie otrzymują za osiągnięcia” (Machaczka, 2001, s. 531).

Definicja wg Ricky Griffina podkreśla, że „pracownicy porównują własny stosunek nakładów do wyników, ze stosunkiem nakładów do wyników u innych, podobnych osób” (Griffin, 2002, s. 437).

Według teorii sprawiedliwości ludzie szacują swój wkład w pracę i uzyskiwane przez siebie wyniki oraz ustalają stosunek wkładu do tych wyników. Następnie dokonują tego samego wobec innych osób w swoim otoczeniu oraz porównują oba współczynniki. To porównanie pozwala im na sprawdzenie, czy proporcja danej osoby jest adekwatna do proporcji obliczonej dla 
innych osób. Gdy te proporcje są równe, pracownik uważa je za sprawiedliwe i satysfakcjonujące. Ten fakt motywuje go do dalszej efektywnej pracy. Jednak Adams zakłada, że również poczucie niesprawiedliwości działa motywująco, gdyż pracownik stara się przywrócić równowagę między proporcjami, zwiększając własną efektywność lub zmieniając kryteria porównań. Na przykład pracownik mający poczucie niedostatecznego wynagrodzenia może stwierdzić, że jego wyniki są wyższe niż dotąd myślał, ponieważ nie uwzględnił w szacunkach pewnych korzystnych dla niego warunków pracy (Adams, 1963, za: Foster, 2003).

Teoria sprawiedliwości opracowana przez Adamsa opiera się na założeniu, że najważniejszym czynnikiem motywacji, efektywności i zadowolenia jest indywidualna ocena przez pracownika sprawiedliwości czy słuszności otrzymanej nagrody. Sprawiedliwość można określić jako stosunek nakładów pracy pracownika (czas, wysiłek, umiejętności, zaangażowanie) do uzyskanych przez niego nagród (odpowiednie wynagrodzenie czy awans) w porównaniu do nagród przyznawanych innym za podobne nakłady. Porównanie takie jest subiektywne, jednak stymuluje do dalszego działaniu.

Przytoczone tutaj teorie motywowania zostały wybrane spośród wielu znanych teorii stosowanych w zarządzaniu przedsiębiorstwem. W praktyce trudno jest stworzyć system motywowania pracowników, który sprawdzałby się w każdych warunkach i w każdej sytuacji. Skonstruowanie systemu motywującego adekwatnego do potrzeb oraz możliwości pracodawcy i jednocześnie spełniającego oczekiwania pracowników jest trudnym zadaniem w obliczu zmieniającej się rzeczywistości i związanych z tym zmian w przedsiębiorstwie.

\section{MOTYWOWANIE PRACOWNIKÓW JAKO ISTOTNY ELEMENT NOWOCZESNEGO ZARZĄDZANIA}

Opracowane przez uczonych teorie motywacji znalazły zastosowanie w zarządzaniu przedsiębiorstwami. Motywowanie pracowników stało się nieodzownym elementem zarządzania, gdyż wiadome jest, że odpowiednia motywacja wyzwala kreatywność, efektywność, entuzjazm, lojalność i zaangażowanie w pracę. Powoduje satysfakcję i zadowolenie z rezultatu wykona- 
nych zadań. Zaspokaja ambicje i skłania do samorealizacji. Motywacja ludzi do pracy wynika $\mathrm{z}$ różnych pobudek, a przede wszystkim $\mathrm{z}$ chęci zaspokojenia potrzeb materialnych i duchowych, rozwoju zainteresowań i zrealizowania aspiracji. Motywy pracy bywają także szczytniejsze i wynikają z przekonań, posłannictwa, ideałów, względów społecznych i kulturowych. Dokładniej obrazują to omówione powyżej teorie motywacji.

„Motywowanie polega na świadomym i celowym oddziaływaniu na motywy postępowania ludzi poprzez stwarzanie środków i oczekiwań” (Matejko, 1993, s. 79).

Rysunek 5.

\section{Motywowanie pracownika}

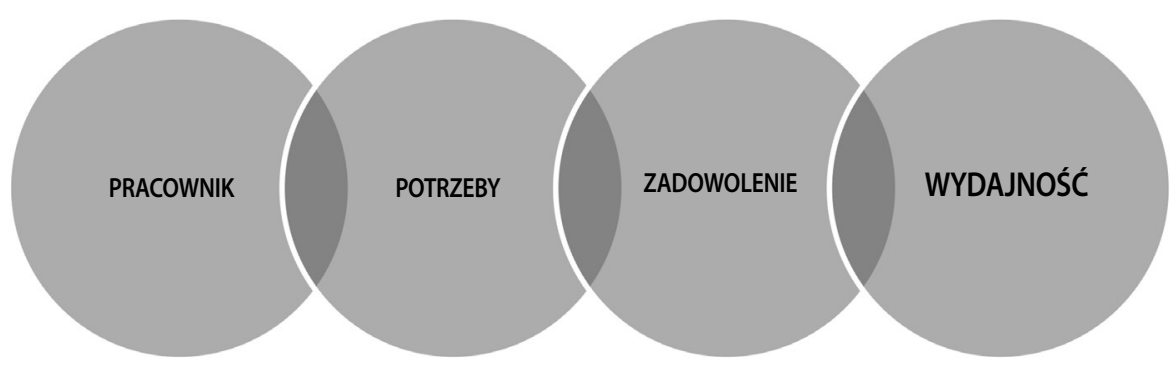

Źródło: opracowanie własne.

Motywowanie według Zdzisława Jasińskiego to oddziaływanie na pracowników poprzez stosowanie rozmaitych form i środków motywacyjnych, tak aby ich zachowania były zgodne $\mathrm{z}$ wolą kierującego, aby zmierzały do zrealizowania postawionych przed nimi zadań (Jasiński, 2007).

Jak wynika z przytoczonych sformułowań, motywowanie jest złożonym procesem, sterującym czynnościami człowieka w celu osiągnięcia określonego celu.

Proces motywowania do pracy zaczyna się od potrzeby (pracownika lub/i przedsiębiorstwa) i poszukiwania sposobu jej zaspokojenia. Ma charakter dwustronny, gdyż między motywowanym i motywującym zachodzą interakcje. 
Proces motywowania do pracy skupia się na:

1. Określeniu celów (zadań) dla pracowników.

2. Identyfikacji i analizie potrzeb.

3. Konstruowaniu i zastosowaniu systemu bodźców (motywów).

4. Obserwacji działań podwładnych i osiągniętych wyników.

5. Osiągnięciu celu.

6. Ocenie skuteczności zaspokojenia potrzeb.

Rysunek 6.

Proces motywowania do prac

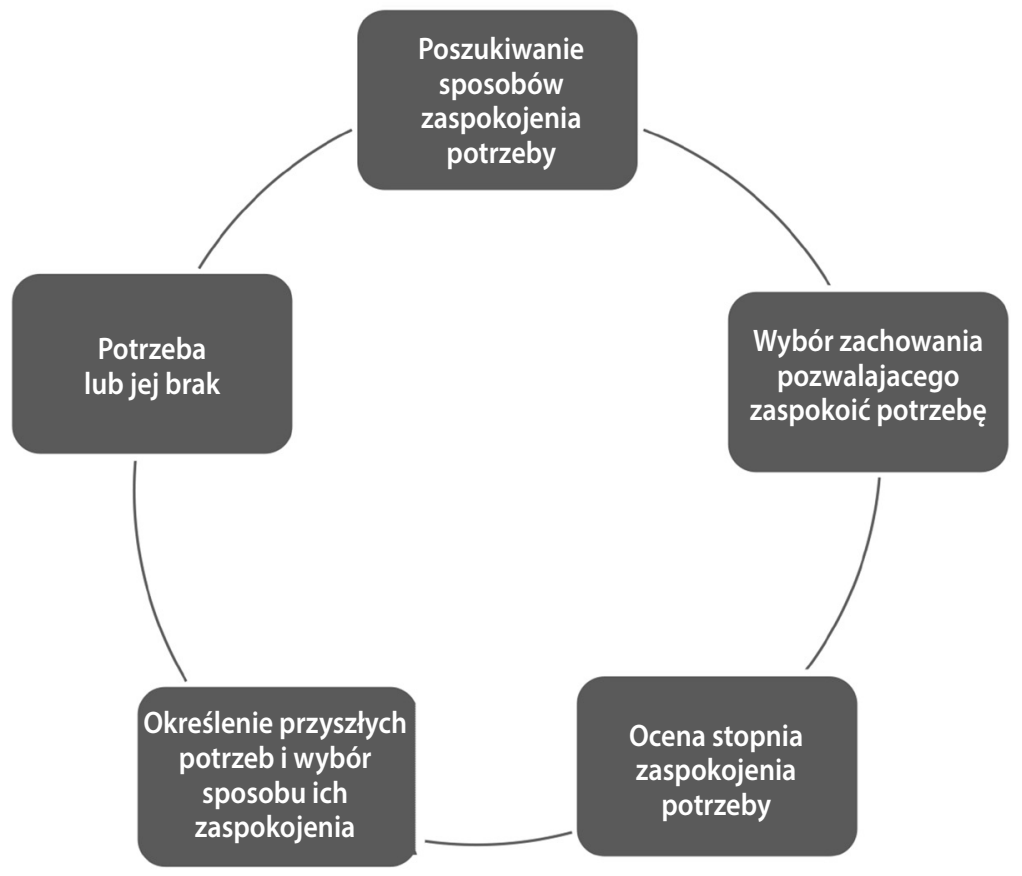

Źródło: R.W. Griffin. (2004). Podstawy zarzadzania organizacjami, Warszawa: Wydawnictwo Naukowe PWN, s. 519.

Proces motywowania jest realizowany przy pomocy odpowiednich środków i narzędzi. Można wśród nich wyodrębnić trzy grupy środków: środki przymusu, zachęty i perswazji. 
Środki przymusu zastosowane w procesie motywacji zakładają podporządkowanie działań pracowników interesom i woli motywującego lub interesom przedsiębiorstwa. Podawane są $\mathrm{w}$ formie poleceń, zaleceń, nakazów, rozkazów i rozporządzeń opartych na wewnętrznych i zewnętrznych normach, instrukcjach, regulaminach i innych uregulowaniach. Stwarzają atmosferę strachu, obawy przed ukaraniem, nie zapewniają bezpieczeństwa. Środkiem przymusu mogą być także własne zobowiązania podjęte dobrowolnie, ale wymuszające określone działania.

Środki zachęty oferują określoną gratyfikację w zamian za oczekiwane działanie. Jest to rodzaj płacy, premii, nagrody, przywilejów skłaniających pracownika do aktywności, zwiększenia efektywności, zaangażowania w celu osiągnięcia założonych zamierzeń. Pozostawiają one pracownikowi margines własnej inwencji i swobody.

Środki perswazji oddziałują na psychikę pracownika w celu zmiany jego postaw, przekonań, nawyków i odczuć. Działają na zasadzie partnerstwa między motywującym a motywowanym. Pozbawione są elementów nakazowych. Stwarzają sytuacje współuczestnictwa w podejmowaniu decyzji i prowadzą do umacniania pozycji pracownika w przedsiębiorstwie. Są to m.in. apele, wezwania, inspiracje, konsultacje, negocjacje, porady.

Doświadczony przedsiębiorca potrafi dokonać właściwego wyboru środka motywującego. Kryterium wyboru zależy od wielu czynników, ale decydującym powinna być jego skuteczność. Środki przymusu mają z reguły mniejszą moc motywowania niż środki zachęty czy perswazji, dlatego ważnym zadaniem przedsiębiorcy jest stosowanie takich środków motywujących, które pracownicy rozumieją i z własnej woli wykonują powierzone zadania, bez oporu i niechęci.

Doświadczenia badawcze przeprowadzone w przedsiębiorstwach wskazują na element płacy i jej pochodnych jako najistotniejszy środek motywujący. Według Marii Wandy Kopertyńskiej, prorektora Uniwersytetu Ekonomicznego we Wrocławiu: „Za pomocą płac można stymulować określone postawy i zachowania ludzi, jak też zachęcać do skuteczniejszej (efektywnej) pracy i rozwoju kompetencji" (Kopertyńska, 2011). Płaca jest nie tylko źródłem dochodu pracownika, określającym jego poziom życia, lecz także wyznacznikiem pozycji społecznej, poczucia własnej wartości, uznania i bezpieczeństwa 
socjalnego. Odpowiednio opracowany system wynagrodzeń w przedsiębiorstwie stanowi ważny środek motywujący pracowników. Jak twierdzi Anna Bagieńska: „System wynagrodzeń jest jednym z najsilniejszych czynników determinujących postawy, motywację i zachowanie pracowników. Właściwie opracowany system przyciąga odpowiednich pracowników, utrzymuje ich w organizacji oraz pobudza do osiągania dobrych efektów pracy" (Bagieńska, 2008).

Choć wynagrodzenie stanowi dla pracownika podstawowy bodziec do pracy, to istotne są również czynniki pozapłacowe, mające duży wpływ na rozwój kariery zawodowej, samorealizację czy podwyższanie kwalifikacji zwiększających wartość rynkową pracownika. M.W. Kopertyńska podzieliła motywatory pozapłacowe na materialne i niematerialne. Wśród czynników materialnych ważną rolę zajmuje system szkoleń pracowniczych. Szkolenia i doskonalenie pracowników zapewniają utrzymanie odpowiedniego standardu wykonywanej pracy, podniesienie ich umiejętności zawodowych dzięki poznaniu nowych technik i technologii, poprawę procesów komunikacyjnych, realizację potrzeb i aspiracji pracowników, co ma zasadnicze znaczenie dla pracownika i przedsiębiorstwa.

Poza tym znaczącymi motywatorami są świadczenia socjalne, ubezpieczenia, opieka medyczna, przywileje związane ze stanowiskiem pracy lub pełnioną funkcją.

Czynniki pozamaterialne rozważane są w trzech obszarach: organizacyjnym, psychologicznym i technicznym.

W obszarze organizacyjnym są to motywatory związane $\mathrm{z}$ organizacją pracy w przedsiębiorstwie, jak dostęp do informacji, elastyczny czas pracy, samodzielność i odpowiedzialność w działaniu. Niebagatelną rolę motywacyjną odgrywa przejrzysty system awansowania.

Obszar psychologiczny zawiera elementy wpływające na atmosferę w pracy, takie jak: przyjazne stosunki koleżeńskie, partnerstwo w działaniu, dobra komunikacja, poczucie bezpieczeństwa pracy, możliwości samorealizacji, okazywanie uznania i aprobaty.

W obszarze technicznym czynnikami motywacyjnymi są warunki pracy, np.: dobrze wyposażone stanowisko pracy, dostęp do nowoczesnych technik i technologii, wykorzystanie systemów informatycznych. 
Schemat 1.

Pozapłacowe czynniki motywacyjne

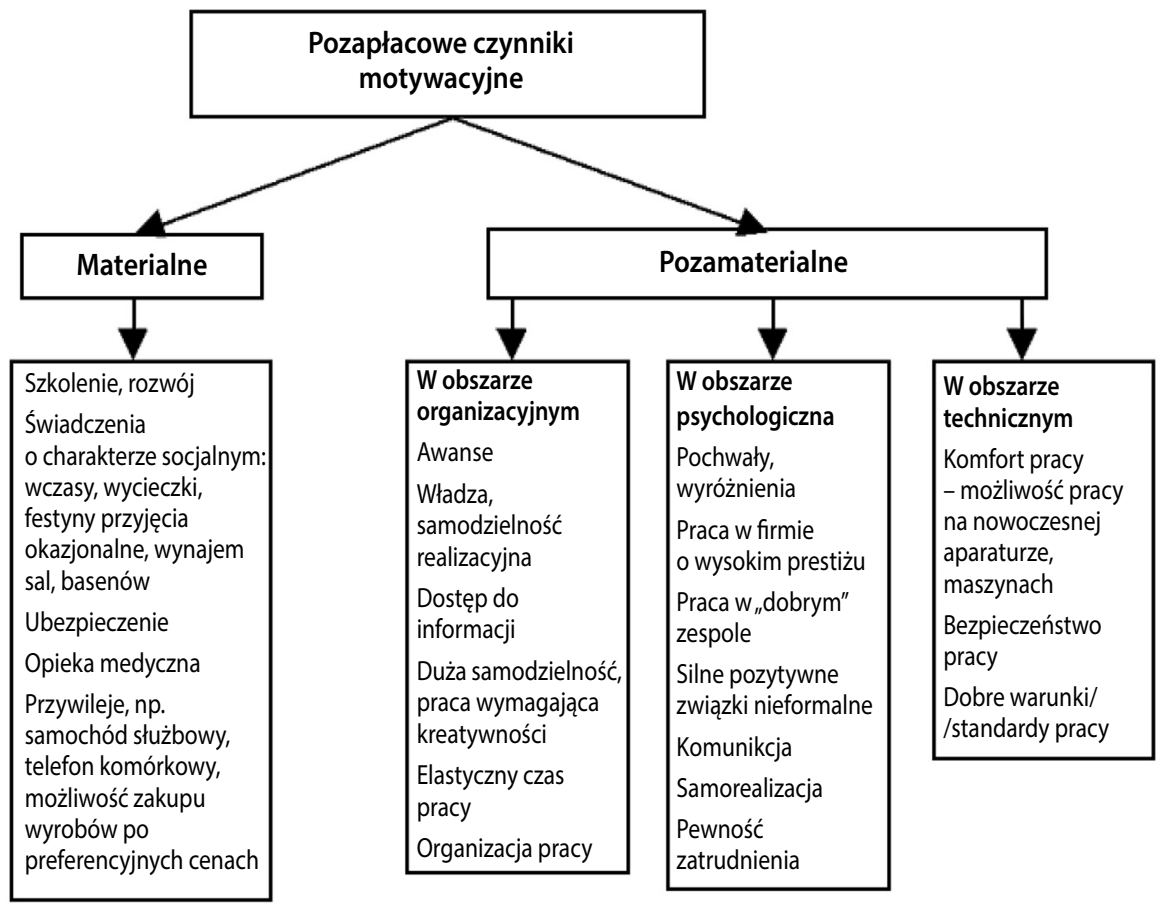

Źródło: M.W. Kopertyńska, System motywacyjny w organizacji (cz. II), wiedza.info.pl) (dostęp: 15.05.2019).

Trudno ustalić wzorzec systemu motywacyjnego, gdyż każdy pracownik jest inny, każdy zespół odznacza się swoistymi cechami, każde przedsiębiorstwo ma zróżnicowane cele. $\mathrm{Z}$ tego powodu budowę skutecznego systemu motywacyjnego należy zaczynać od dogłębnego zbadania potrzeb pracowników, ich cech osobowości, sytuacji życiowej, środowiska pracy, wiedzy i umiejętności, przekonań i oczekiwań, uwzględniając specyfikę i potrzeby przedsiębiorstwa. Funkcjonowanie systemu motywacyjnego można podzielić na trzy podstawowe grupy działań:

- motywowanie pracownika przez pracodawcę przeprowadzane pod kątem zaspokajania jego indywidualnych potrzeb i oczekiwań; 
- wzajemna motywacja pracowników, dzięki pracy w grupach i zespołach, opartej na wzajemnych relacjach, stosunkach koleżeńskich, współdziałaniu, pomocy i wsparciu, odpowiedzialności, obowiązkowości, partnerstwie;

- motywacja w przedsiębiorstwie, opierająca się na nowoczesnym zarządzaniu, przejrzystych systemach wynagradzania i awansowania, stworzeniu systemu szkoleń i komfortowych warunków pracy.

Poglądy badaczy na temat zarządzania przez motywację są podzielone. Mimo niewątpliwych opinii pozytywnych są też wypowiedzi podające w wątpliwość rolę motywacji w efektywnym zarządzaniu organizacją. Burkard Sievers (Sievers, 1986), krytykuje nowoczesne koncepcje motywacji, twierdząc, że nie mają one realnego związku z ludźmi w organizacjach. Uważa on, że teorie koncentrują się na tym, jak pracowników motywować do pracy, natomiast pomijają całkowicie fakt, że wiele organizacji oferuje ludziom bezsensowną, ograniczoną i nienaturalną pracę, do której „niemotywowani” nigdy sami by nie odczuwali skłonności ani potrzeby. Według niego teoretycy motywacji poszukują relacji przyczynowo-skutkowych na poziomie indywidualnego pracownika, nie zważając na szerszy kontekst. Z teorii mającej oferować zrozumienie ludzkiego działania motywacja przekształciła się w narzędzie wpływania na ludzi, manipulowania nimi (Kostera, Kownacki, Szumski, 2007). Teorie motywacji na ogół roszczą sobie pretensje do bycia uniwersalnymi i ogólnie obowiązującymi, lecz nie biorą pod uwagę kontekstu politycznego, społecznego ani kulturowego, w którym działają ludzie i organizacje. Zdaniem Sieversa motywacja stała się bardziej rozpowszechnionym tematem badań i rozważań, od czasu gdy większości ludzi utraciła sens pracy. Pracownicy wykonujący sfragmentaryzowaną, monotonną, rutynową i nudną pracę muszą zostać do niej zmuszeni lub nakłonieni - poprzez surogat sensu, a więc motywację. W związku ze zmianami zachodzącymi we współczesnym świecie zmienia się również środowisko pracy, które będzie wymagało od pracowników specyficznego zbioru kompetencji i umiejętności przetwarzania różnorodnych informacji, a od przywódców - nowego stylu zarządzania. Najważniejsze wyzwania w zarządzaniu kapitałem ludzkim w nowoczesnej koncepcji zarządzania 4.0 to: 
- rekrutacja pracowników o odpowiednich kwalifikacjach,

- efektywne motywowanie pracowników,

- wzbudzanie zaangażowania pracowników poprzez prowadzenie właściwych szkoleń,

- zapewnienie efektywniejszej komunikacji wewnątrz organizacji,

- budowanie współpracy pomiędzy różnymi pokoleniami pracowników oraz zarządzanie różnorodnością kulturową.

Wyzwania te stawiają określone zadania przed menadżerami we wszystkich typach przedsiębiorstw. Opracowanie odpowiedniego systemu motywowania pracowników do twórczej i efektywnej pracy to podstawowa działalność kierownictwa otwierająca drogę do sukcesu firmy na rynku pracy. Nie jest to zadania łatwe, gdyż wymagania przedsiębiorców rosną, a oczekiwania pracowników często rozmijają się z nimi. Brak jest motywatorów, które zadowoliłyby każdego. Materialne czynniki motywacyjne są niejednokrotnie niezadawalające. Wtedy dużego znaczenia nabierają czynniki pozamaterialne - przede wszystkim psychologiczne i społeczne. Na plan pierwszy wysuwają się zagadnienia uzyskiwania satysfakcji zawodowej, rozwijania swoich umiejętności, podwyższania kwalifikacji oraz możliwości szybkiego awansowania. Reasumując, należy podkreślić, że motywacja w procesie pracy jest niezwykle ważna. Właściwe motywowanie pracowników pozwala skuteczniej osiągać zamierzone cele, co w powiązaniu z zadowoleniem zatrudnionych osób sprzyja tworzeniu korzystnej atmosfery pracy i większemu zaangażowaniu oraz kreatywności pracowników na wszystkich szczeblach organizacji.

\section{ZAKOŃCZENIE}

Motywowanie i inspirowanie pracowników do wydajnej, konstruktywnej i skutecznej pracy zawsze odgrywało ważną rolę w procesie zarządzania, bez względu na rodzaj i wielkość przedsiębiorstwa. W literaturze przedmiotu znajduje się potwierdzenie znaczenia motywowania w zarządzaniu: „Od zawsze, niezależnie $\mathrm{w}$ jakim paradygmacie określano determinanty skuteczności systemów oraz narzędzi oddziaływania i pobudzania ludzi do realizacji celów organizacyjnych, kluczową kwestią był problem racjonalnego, rentownego i zarazem motywacyjnego opłacania udziału człowieka w procesie 
pracy" (Kawka, 2011). Tym bardziej nabiera to znaczenia obecnie, w dobie społeczeństwa ciągle kształcącego się i doskonalącego swoje kompetencje oraz $\mathrm{w}$ gospodarce opartej na wiedzy. Z tego względu w artykule podjęto problematykę motywowania pracowników opartą na naukowych teoriach motywowania, ze szczególnym uwzględnieniem motywatorów pozapłacowych, odnoszących się przeważnie do pracowników wysoko wykwalifikowanych. Z punktu widzenia przedsiębiorcy niecelowe jest kierowane czynników motywacyjnych wyższego rzędu do pracowników o niskich kwalifikacjach, których łatwo zastąpić innymi. Między innymi dlatego liczba takich motywatorów jest stosunkowo niewielka (Beck-Krala, 2011). Zdaniem wielu autorów w przypadku niezaspokojonych (lub nie do końca zaspokojonych) potrzebach finansowych pracowników motywowanie przy pomocy czynników pozamaterialnych nie przynosi spodziewanych efektów, a generuje dodatkowe koszty. Z badań przeprowadzonych przez firmy wynika, że oprócz czynników płacowych najbardziej cenione są takie motywatory jak: możliwość doskonalenia kwalifikacji, atrakcyjność wykonywanych zadań, poczucie samorealizacji, możliwość zachowania właściwych proporcji pomiędzy pracą a życiem prywatnym, wyposażenie stanowiska pracy, prestiż firmy na rynku i poczucie przynależności do zespołu.

\section{Literatura}

Bagieńska, A. (2008). Rola systemu wynagrodzeń we współczesnej gospodarce, „Zeszyty Naukowe Politechniki Białostockiej" nr 11, http://pbc.biaman.pl/Content /9875/ ZN+EiZ+nr+11.pdf (dostęp: 20.05.2019).

Barbachowska, B., Dziurzyński, K., Such-Pyrgiel, M., Szejniuk, A. (2014). Bezrobocie a bezpieczeństwo społeczne. Analiza zjawiska na przykładzie powiatu podwarszawskiego, „Journal of Modern Science” nr 21(2), s. 179-209. ISSN 1734-2031.

Borkowska, S. (1985). System motywowania w przedsiębiorstwie, Warszawa: Wydawnictwo Naukowe PWN. ISBN 8301065664.

Borkowska, S. (2004). Strategie wynagrodzeń, Kraków: Oficyna Ekonomiczna. ISBN 8389355345.

Beck-Krala, E. (2011). Efektywne programy świadczeń pracowniczych. W: B. Urbaniak (red.), Efektywność zarządzania zasobami ludzkimi, Łódź: Wydawnictwo Uniwersytetu Łódzkiego. ISBN 9788375255461. 
Cieszewska, N. i Wilczek, A. (2010). Motywowanie pracowników a efektywność ich pracy. W: J.P. Lendzion, M. Szczepanik (red.), Praktyka zarządzania zasobami ludzkimi, Łódź: Wydawnictwo Media Press. ISBN 9788361215271.

Griffin, R.W. (1997). Podstawy zarzadzania organizacjami, Warszawa: Wydawnictwo Naukowe PWN. ISBN 8301120193.

Jasiński, Z. (2007). Motywowanie w przedsiębiorstwie. Uwalnianie ludzkiej produktywności Materialne, organizacyjne i psychologiczne motywatory, Warszawa: Wydawnictwo Agencja Wydawnicza Placet. ISBN 8385428291.

Kawka, T. (2011). Uwarunkowania efektywności systemów wynagrodzeń nowej gospodarki. W: B. Urbaniak (red.), Efektywność zarządzania zasobami ludzkimi, Łódź: Wydawnictwo Uniwersytetu Łódzkiego. ISBN 9788375255461.

Kopaliński, W. (1968). Słownik wyrazów obcych i zwrotów obcojęzycznych, Warszawa: Wydawnictwo Wiedza Powszechna.

Kopertyńska, M.W. (2008). Motywowanie pracowników - teoria i praktyka, Warszawa: Wydawnictwo Placet. ISBN 9788374881371.

Kostera, M., Kownacki, S., Szumski, A. (2007). Zachowania organizacyjne: motywacja, przywództwo, kultura organizacyjna. W: A. Koźmiński (red.), Zarządzanie. Teoria i praktyka, Warszawa: Państwowe Wydawnictwo Naukowe PWN. ISBN 9788301151423.

Kozłowski, W. (2017). Zarządzanie motywacja pracowników, Warszawa: Wydawnictwo CeDeWu. ISBN 9788375569186.

Lenik P. (2012). Motywatory pozapłacowe, czyli droga do nowej jakości pracowników: przedsiębiorstwa i administracja publiczna. Warszawa: Wydawnictwo Difin. ISBN 9788376415314.

Machaczka, J. (2001). Podstawy zarzadzania, Kraków: Wydawnictwo Akademii Ekonomicznej. ISBN 8372520941.

Masłyk-Musiał, E. (2011). Strategiczne zarzadzanie zasobami ludzkimi, Warszawa: Oficyna Wydawnicza Politechniki Warszawskiej. ISBN 9788372079350.

Matejko, A,J., (1993). Kilka refleksji na temat zarzadzania strategicznego, „Organizacja i Kierowanie" nr 2.

Penc, J. (2000). Motywowanie w zarządzaniu, Kraków: Wydawnictwo Profesjonalnej Szkoły Biznesu.

Schermerhorn, J.R. (2008). Zarzadzanie - kluczowe koncepcje, Warszawa: Wydawnictwo PWE. ISBN 9788320817836. 
Stoner, J.A., Freeman, R.E., Gilbert Jr, D.R. (1997). Kierowanie, Warszawa: Wydawnictwo PWE. ISBN 8320808618.

Szejniuk, A. (2016). Etyka menedżerska w zarzadzaniu zasobami ludzkimi, Journal of Modern Science, 28(1), 89-104.

Szejniuk, A. (2017). Rola zasobów ludzkich w strategicznym zarządzaniu organizacją, „Journal of Modern Science” nr 32(1), s. 305-317. ISSN 1734-2031.

Waters, D. (2007). Zarzadzanie operacyjne: towary i ustugi, Warszawa: Wydawnictwo Naukowe PWN. ISBN 9788301153960.

\section{Źródła internetowe}

http://wiedzainfo.ue.wroc.pl/wyklady/120/system_motywacyjny_w_organizacji_ii. html (dostęp: 15.05.2019). 